\title{
ASSOCIATION BETWEEN ANXIETY AND DEPRESSION AND QUALITY OF LIFE OF CHRONIC RENAL PATIENTS ON HEMODIALYSIS
}

\author{
Ana Carolina Ottaviani ${ }^{1}$, Loren Carolina Betoni ${ }^{2}$, Sofia Cristina Iost Pavarini ${ }^{3}$, Karina Gramani Say ${ }^{4}$, Marisa \\ Silvana Zazzetta ${ }^{5}$, Fabiana de Souza Orlandi ${ }^{6}$
}

\footnotetext{
${ }^{1}$ 'Master's student, Programa de Pós-Graduação em Enfermagem, Universidade Federal de São Carlos (UFSCar). São Carlos, São Paulo, Brazil. E-mail: anacarolina_ottaviani@hotmail.com

${ }^{2}$ UUndergraduate student in Gerontology at UFSCar. São Carlos, São Paulo, Brazil. E-mail: loren.bett@hotmail.com

${ }^{3}$ Ph.D. in Education. Professor, Departamento de Gerontologia, UFSCar. São Carlos, São Paulo, Brazil. E-mail: sofiapavarini@gmail.com

${ }_{4}^{4}$ Ph.D. in Physiotherapy. Professor, Departamento de Gerontologia, UFSCar. São Carlos, São Paulo, Brazil. E-mail: kagramanis@ yahoo.com.br

${ }^{5}$ 'Ph.D. in Social Service. Professor, Departamento de Gerontologia, UFSCar. São Carlos, São Paulo, Brazil. E-mail: marisazazzetta@ yahoo.com.br

${ }_{6}^{6}$ Ph.D. in Nursing. Professor, Departamento de Gerontologia, at UFSCar. São Carlos, São Paulo, Brazil. E-mail: forlandi@ufscar.br
}

\begin{abstract}
To analyze the relationship between anxiety and depression and quality of life in chronic renal failure patients on hemodialysis. This is a correlational study with a cross-sectional, quantitative approach, conducted with 100 kidney patients under treatment at a Renal Replacement Therapy Unit in the state of São Paulo. Data were collected using a sociodemographic questionnaire, Hospital Anxiety and Depression Scale and Kidney Disease and Quality of Life Short-Form. A negative correlation was found between anxiety and depression and the quality of life domains. In addition, the average scores on the Kidney Disease and Quality of Life Short-Form were significantly lower in patients with anxiety and depressive symptoms. In conclusion, there is a negative correlation between depression and anxiety and the health-related quality of life of chronic renal failure patients on hemodialysis.
\end{abstract}

DESCRIPTORS: Anxiety. Depression. Quality of life. Renal insufficiency, chronic. Nursing.

\section{ASSOCIAÇÃO ENTRE ANSIEDADE E DEPRESSÃO E A QUALIDADE DE VIDA DE PACIENTES RENAIS CRÔNICOS EM HEMODIÁLISE}

RESUMO: O objetivo foi analisar a relação entre a ansiedade e depressão e qualidade de vida de pacientes renais crônicos em tratamento hemodialítico. Estudo correlacional, de corte transversal, com abordagem quantitativa, realizado com 100 pacientes renais em tratamento em uma Unidade de Terapia Renal Substitutiva do interior do Estado de São Paulo. Os dados foram coletados a partir do questionário para caracterização sociodemográfica, Escala Hospitalar de Ansiedade e Depressão e Kidney Disease and Quality of Life Short-Form. Verificou-se a existência de correlação negativa entre a ansiedade e depressão com os domínios de qualidade de vida. Ademais, a média dos domínios do Kidney Disease and Quality of Life Short-Form foram significativamente menores nos pacientes com sintomas ansiosos e depressivos. Conclui-se que existe correlação negativa entre a depressão e ansiedade com a qualidade de vida relacionada à saúde de pacientes com doença renal crônica em tratamento hemodialítico.

DESCRITORES: Ansiedade. Depressão. Qualidade de vida. Insuficiência renal crônica. Enfermagem.

\section{ASOCIACIÓN ENTRE LA ANSIEDAD Y LA DEPRESIÓN CON LA CALIDAD DE VIDA DE LOS PACIENTES RENALES CRÓNICOS EN HEMODIÁLISIS}

RESUMEN: Analizar la relación entre ansiedad y depresión con la calidad de vida de los pacientes renales crónicos en hemodiálisis. Estudio correlacional, transversal, con un enfoque cuantitativo, realizado con 100 pacientes renales en tratamiento en una Unidad de Terapia de Reemplazo Renal en el estado de São Paulo. Los datos fueron obtenidos a partir del cuestionario de variables sociodemográficas, Hospital Anxiety and Depression Scale y Kidney Disease and Quality of Life Short Form. Se encontró una correlación negativa entre la ansiedad y depresión con los dominios de calidad de vida. Además, las puntuaciones medias de los dominios Kidney Disease and Quality of Life Short Form fueron significativamente inferiores en los pacientes con ansiedad y los síntomas depresivos. Concluimos que existe una correlación negativa entre la depresión y la ansiedad con la calidad de vida de los pacientes con enfermedad renal crónica en hemodiálisis.

DESCRIPTORES: Ansiedad. Depressión. Calidade de vida. Insuficiencia renal crónica. Enfermería. 


\section{INTRODUCTION}

Chronic renal failure (CRF) is the progressive and irreversible loss of the kidney function, classified according to the glomerular filtration rate. ${ }^{1}$ Today, it is considered a severe public health problem around the world. A substantial increase is expected in the number of patients treated using hemodialysis. ${ }^{2}$ The world is facing an epidemic of $\mathrm{CRF}$ and the number of these patients is growing on a larger scale in developing countries. ${ }^{3}$

CRF patients in renal replacement therapy are subject to a higher prevalence of mood disorders than the general population. ${ }^{4}$ The predominance rates of anxiety and depression in hemodialysis patients are high, corresponding to between $30 \%$ and $45 \%$ and between $20 \%$ and $30 \%$, respectivamente. . $^{5-7}$ This condition can represent an increase in the morbidity and mortality of dialysis patients, compromise their treatment compliance and modulate their immunological and nutritional situation, due to the depression or anxiety symptoms as well as to associated symptoms, such as loss of concentration, loss of motivation, sleep disorders, fatigue, depressive mood and difficulty to understand information. ${ }^{4,8}$

Evidence exists in the literature that anxiety and depression are associated with a drop in quality of life (QoL) ${ }^{6,8}$ QoL is a multidimensional and subjective concept and a multifactorial construct. It is a useful variable to determine the global impact of diseases and medical treatments from an individual perspective, and its measure can be useful in research and clinical practice to demonstrate the possible benefit of therapeutic interventions. ${ }^{9}$

To avoid bias and distinguish between QoL in its broadest sense and its specific application related to medical and clinical parameters, the term healthrelated quality of life (HRQoL) is frequently used..$^{10}$ HRQoL addresses relevant social aspects, comprising the perceived health, social, psychological and physical functions and related health damage. Therefore, HRQoL assessment has turned into an important indicator of CRF patients' health and wellbeing. Its results are frequently used to determine the effectiveness of health care and the treatment effects, as well as resource allocation and health policy making. ${ }^{11}$

Considering the impacts of mood disorders associated with hemodialysis treatment according to different studies, the importance of this research is based on the need to increase the related knowledge and discussion. ${ }^{5-7}$ In addition, this study is expected to contribute to the discussion between nurses and other health professionals working at Brazilian di- alysis centers about possible ways to improve the HRQoL of chronic renal patients. The importance of nursing professionals in individual care delivery should be highlighted, as well as in the appropriate planning of care, with a view to guaranteeing the quality of health care. CRF and dialysis treatment can cause losses and changes that entail alterations in terms of physical and emotional integrity, reflecting in a worse quality of life. ${ }^{6}$

In view of the above, the objective in this study was to analyze the relation between anxiety and depression and the quality of life of chronic renal patients under hemodialysis.

\section{METHOD}

Quantitative and cross-sectional correlational study, developed at a Renal Replacement Service in the interior of the State of São Paulo. During the research period, the Nephrology Service attended to 150 patients from the Unified Health System and private health insurance beneficiaries, covering the cities of São Carlos, Porto Ferreira, Descalvado, Ibaté, Ribeirão Bonito and Itirapina.

A convenience sample was dimensioned, totaling 100 participants who complied with the following eligibility criteria: age 18 years or more, diagnosed with terminal CRF and under hemodialysis treatment. After the invitation, information was provided on this study and possible doubts were solved. After they had agreed to participate in the study, all respondents signed the Free and Informed Consent Form.

To collect the data, a Sociodemographic and Clinical Questionnaire, the Hospital Anxiety and Depression Scale (HADS) and the Kidney Disease and Quality of Life Short-Form (KDQOL-SF) were used. The sociodemographic and health assessment questionnaire was elaborated for this study. The following sociodemographic variables were included: gender, age, marital status, occupation, income, education and religion. The health status was characterized by listing information on the causes of the renal disease and the interest in having kidney transplantation.

The HADS, elaborated in 1983 and adapted and validated for the Portuguese language in 1995, assesses the anxiety and depression levels. ${ }^{12-13}$ It contains 14 multiple-choice questions and consists of two subscales, one related to anxiety (HADS-A) and the other to depression (HADS-D), with seven items in each domain. The score ranges from 0 to 21 in each subscale. For the sake of interpretation, 
it is considered that, the higher the score, the more severe the symptoms. In this research, the cut-off points informed in the Brazilian literature were adopted, ${ }^{12}$ in that scores inferior to eight do not indicate anxiety and depression symptoms, while scores of eight or higher signal such symptoms.

The KDQOL-SF, developed by the Working Group in 1997 and translated and validated for the Brazilian context in 2003, assesses the HRQoL in the context of CRF and is applicable to patients in some kind of dialysis program. ${ }^{14}$ The questionnaire consists of 80 items, divided in 19 dimensions, 11 of which are specific to the chronic renal disease and eight generic. These are analyzed separately, resulting in mean coefficients and identifying the actual problems related to the patients' health. The final score ranges from zero to 100, in which 100 is the best classification and zero the worst in the assessment of the patient's quality of life.

These tools were applied before the hemodialysis session or, if that was impossible, during the first two hours of the treatment. As some of the participants could present visual problems and/or low education levels, the tool was applied through an individual interview between June and August 2014. No cognitive assessment was undertaken as all participants were able to answer the questionnaires without the help of a companion.

The data were inserted in an Excel worksheet and transported for analysis to the software Statistical Package for the Social Sciences (SPSS for Windows), version 22.0. For the descriptive analysis of the data, the position (mean, minimum and maximum) and dispersion (standard deviation) measures were calculated. Cronbach's alpha (a) was used to verify the internal consistency of the HADS and KDQOL-SF. In this study, the reference coefficient $a \geq 0.70$ was adopted as satisfactory. ${ }^{15}$

In addition, correlational calculations were done (Pearson's correlation coefficient) and Student's t-test to compare the QoL of the groups with and without the presence of anxiety and depression symptoms. In this study, the magnitude of the correlations was classified as weak $(<0.3)$; moderate (0.3 to 0.59$)$; strong (0.6 to 0.9$)$ and perfect (1.0). ${ }^{16}$ The significance level adopted for the statistical tests was $\mathrm{p} \leq 0.05$.

Approval for the study was obtained from the Research Ethics Committee at Universidade Federal de São Carlos (Opinion 509.241/2014; CAAE 25424113.2.0000.5504). The research development complied with the ethical standards for research involving human beings (Resolution 466/2012).

\section{RESULTS}

The study included 100 patients, characterized by the predominance of men $(66.0 \%)$, with a mean age of $53.25( \pm 14.72)$ years. Most patients had a fixed partner $(74.0 \%)$, the mean length of education was $8.41( \pm 11.22)$ years, with a prevalence of unfinished primary education $(46.0 \%)$. As for the monthly income, $61.0 \%$ received only one minimum wage and $38 \%$ between two and five minimum wages (minimum wage at the time of the data collection: R\$ 724.00 per month). In total, $79.0 \%$ did not engage in any kind of paid work. The predominant religion was Catholic $(58.0 \%), 67.0 \%$ being practicing. The full data on the chronic renal patients' characteristics are displayed in Table 1.

Table 1 - Sociodemographic and clinical characteristics of 100 chronic renal patients. São Carlos-SP, 2015

\begin{tabular}{|c|c|c|}
\hline Variable & $\mathbf{n}$ & $\%$ \\
\hline \multicolumn{3}{|l|}{ Age range } \\
\hline 18 to 59 years & 60 & 60.0 \\
\hline 60 years or older & 40 & 40.0 \\
\hline \multicolumn{3}{|l|}{ Sex } \\
\hline Male & 66 & 66.0 \\
\hline Female & 34 & 34.0 \\
\hline \multicolumn{3}{|l|}{ Marital situation } \\
\hline With fixed partner & 74 & 74.0 \\
\hline Without fixed partner & 26 & 26.0 \\
\hline \multicolumn{3}{|l|}{ Education } \\
\hline Illiterate & 3 & 3.0 \\
\hline 1 to 4 years & 46 & 46.0 \\
\hline 5 to 9 years & 21 & 21.0 \\
\hline 10 years or more & 30 & 30.0 \\
\hline \multicolumn{3}{|l|}{ Per capita income } \\
\hline Up to 1 minimum wage & 58 & 58.0 \\
\hline 1.1 to 3 minimum wages & 38 & 38.0 \\
\hline 3.1 or more minimum wages & 4 & 4.0 \\
\hline \multicolumn{3}{|l|}{ Paid work } \\
\hline Yes & 79 & 79.0 \\
\hline No & 21 & 21.0 \\
\hline \multicolumn{3}{|l|}{ Religion } \\
\hline Catholic & 58 & 58.0 \\
\hline Evangelic & 21 & 21.0 \\
\hline Christian Congregation & 08 & 8.0 \\
\hline Spiritist & 04 & 4.0 \\
\hline Adventist & 03 & 3.0 \\
\hline Assembly of God & 02 & 2.0 \\
\hline Jehovah's Witness & 02 & 2.0 \\
\hline None & 02 & 2.0 \\
\hline \multicolumn{3}{|l|}{ Baseline disease } \\
\hline Arterial Hypertension & 38 & 38.0 \\
\hline Diabetes Mellitus & 21 & 21.0 \\
\hline
\end{tabular}


Glomerular diseases

Other causes

Does not know

$21 \quad 21.0$

$16 \quad 16.0$

$04 \quad 4.0$

Interest in renal transplantation

Yes

No

$58 \quad 58.0$

$42 \quad 42.0$

As regards the main causes of CRF, systemic arterial hypertension prevailed $(38.0 \%)$, followed by type 2 diabetes mellitus (21.0\%). Little more than the majority $(58.0 \%)$ informed interest in having the renal transplantation (Table 1 ).

Concerning the results of the anxiety and depression assessment, the mean score for the total scale was $6.20( \pm 4.43)$, ranging from 0 to 13 . With regard to the internal consistency, Cronbach's alpha corresponded to 0.79 , indicating satisfactory reliability. The mean HADS-A score was 5.05 (3.25), ranging from 0 to 17 . The mean HADS-D score was $4.08( \pm 3.43)$. Cronbach's alpha was satisfactory for both domains, corresponding to 0.80 and 0.73 , respectively.

Adopting the cut-off point $\geq 8$ to classify the symptom intensity, $33.0 \%$ of the respondents suffered from moderate to severe anxiety symptoms.

The mean scores on the specific part of the KDQOL-SF for chronic renal failure identify the fol- lowing mean dimension scores in rising order: Work status (17.00); Burden of kidney disease (38.31); Patient satisfaction (53.66); Sexual function (64.40); Sleep (72.22); Quality of social interaction (73.46); Effects of kidney disease (76.25); Dialysis staff encouragement (83.12); Symptoms/ problems (82.70); Social support (86.66) and Cognitive function (88.06).

For the generic dimensions, the mean scores in rising order were: Emotional function (41.99); Physical function (46.00); General health (56.65); Emotional wellbeing (61.84); Energy/fatigue (63.05); Physical functioning (65.35); Sexual function (68.62) and Pain (73.03). As for the internal consistency of the KDQOL-SF, most of the dimensions obtained satisfactory Cronbach's alpha coefficients $(\geq 0.70)$.

Table 2 displays the comparison of means, using Student's t-test, of the KDQOL-SF dimensions between the groups with or without the presence of anxious and depressive symptoms, based on the preset cut-off point. The mean QoL was significantly lower in patients with anxious and depressive symptoms $(\geq 8)$ than in patients without the presence of these symptoms $(<8)$.

It should be highlighted that the dimensions without statistically significant differences between the two groups are not displayed in Table 2.

Table 2 - Statistical hypothesis test Student's $\mathrm{t}$ for mean KDQOL-SF scores between groups with and without anxious and depressive symptoms. São Carlos-SP, 2015

\begin{tabular}{|c|c|c|c|c|c|c|}
\hline \multirow[t]{2}{*}{ Dimensions } & \multicolumn{3}{|c|}{ Anxiety } & \multicolumn{3}{|c|}{ Depression } \\
\hline & $<8$ & $\geq 8$ & $p$ value & $<8$ & $\geq 8$ & p value \\
\hline Symptoms/problems & 75.18 & 86.41 & 0.020 & 75.24 & 84.23 & 0.033 \\
\hline Work status & 9.09 & 20.89 & 0.042 & 5.88 & 19.27 & 0.026 \\
\hline Cognitive function & 81.61 & 91.24 & 0.054 & 78.82 & 89.95 & 0.015 \\
\hline Quality of social interaction & 65.65 & 77.31 & 0.030 & 68.62 & 74.45 & 0.083 \\
\hline Sexual function & 49.10 & 71.00 & 0.014 & 72.50 & 63.41 & 0.157 \\
\hline Sleep & 63.18 & 76.67 & 0.271 & 67.05 & 73.28 & 0.020 \\
\hline Social support & 85.35 & 87.31 & 0.031 & 84.31 & 87.14 & 0.057 \\
\hline Dialysis team encouragement & 78.40 & 83.95 & 0.065 & 78.67 & 82.83 & 0.039 \\
\hline Patient satisfaction & 51.00 & 54.97 & 0.026 & 54.90 & 53.41 & 0.044 \\
\hline Physical function & 29.54 & 54.10 & 0.001 & 33.82 & 48.50 & 0.025 \\
\hline Energy/fatigue & 52.72 & 68.13 & 0.033 & 48.52 & 66.02 & 0.006 \\
\hline
\end{tabular}

As regards the correlations between the QoL dimensions and anxiety and depression on the HADS scale, a negative correlation was found. As the QoL drops, the anxious and/or depressive symptoms increase, being inversely proportional.

In Table 3, negative and moderate correlations are observed, specifically between anxiety and the dimensions: Quality of social interaction $(\mathrm{r}=-0.533$; $\mathrm{p}<0.000)$; Pain $(\mathrm{r}=-0.532 ; \mathrm{p}<0.000)$; Emotional wellbeing $(\mathrm{r}=-0.697 ; \mathrm{p}<0.000)$; and Energy/ fatigue $(\mathrm{r}=-0.529 ; \mathrm{p}<0.01)$. The weak correlations are evident in the domains Symptoms/problems ( $\mathrm{r}=-$ $0.475 ; \mathrm{p}<0.000)$; Effects of kidney disease $(\mathrm{r}=-0.416$; $\mathrm{p}<0.000)$; Kidney disease burden $(\mathrm{r}=-0.401 ; \mathrm{p}<0.03)$; Physical function $(\mathrm{r}=-0.421 ; \mathrm{p}<0.000)$; Emotional function $(\mathrm{r}=-0.456 ; \mathrm{p}<0.000)$. 
Concerning the relation between QoL and depression, a weak negative correlation is found with the Energy/fatigue dimension only $(\mathrm{r}=-0.489$; $\mathrm{p}<0.01$ ) (Table 3).

Table 3 - Pearson's correlation between mean scores in KDQOL-SF dimensions for HADS. São CarlosSP, 2015

\begin{tabular}{|c|c|c|c|}
\hline \multirow{2}{*}{ Dimensions } & \multirow{2}{*}{ Correlation } & \multicolumn{2}{|c|}{ Hospital Anxiety and Depression Scale } \\
\hline & & Anxiety & Depression \\
\hline \multirow{2}{*}{ Symptoms/problems } & $\mathrm{r}$ & -0.475 & -0.254 \\
\hline & $\mathrm{p}$ & 0.000 & 0.011 \\
\hline \multirow{2}{*}{ Effects of kidney disease } & $\mathrm{r}$ & -0.416 & -0.226 \\
\hline & $\mathrm{p}$ & 0.000 & 0.024 \\
\hline \multirow{2}{*}{ Burden of kidney disease } & $\mathrm{r}$ & -0.401 & -0.207 \\
\hline & $\mathrm{p}$ & 0.003 & 0.039 \\
\hline \multirow{2}{*}{ Work status } & $\mathrm{r}$ & -0.95 & -0.132 \\
\hline & $\mathrm{p}$ & 0.349 & 0.189 \\
\hline \multirow{2}{*}{ Cognitive function } & $\mathrm{r}$ & -0.392 & -0.349 \\
\hline & $\mathrm{p}$ & 0.000 & 0.000 \\
\hline \multirow{2}{*}{ Quality of social interaction } & $\mathrm{r}$ & -0.533 & -0.285 \\
\hline & $\mathrm{p}$ & 0.000 & 0.004 \\
\hline \multirow{2}{*}{ Social function } & $\mathrm{r}$ & -0.381 & -0.198 \\
\hline & $\mathrm{p}$ & 0.013 & 0.210 \\
\hline \multirow{2}{*}{ Sleep } & $\mathrm{r}$ & -0.327 & -0.192 \\
\hline & $\mathrm{p}$ & 0.001 & 0.056 \\
\hline \multirow{2}{*}{ Social support } & $\mathrm{r}$ & -0.143 & -0.063 \\
\hline & $\mathrm{p}$ & 0.156 & 0.535 \\
\hline \multirow{2}{*}{ Dialysis team encouragement } & $\mathrm{r}$ & -0.176 & -0.040 \\
\hline & $\mathrm{p}$ & 0.081 & 0.691 \\
\hline \multirow{2}{*}{ Patient satisfaction } & $\mathrm{r}$ & -0.157 & -0.59 \\
\hline & $\mathrm{p}$ & 0.118 & 0.560 \\
\hline \multirow{2}{*}{ Physical functioning } & $\mathrm{r}$ & -0.379 & -0.288 \\
\hline & $\mathrm{p}$ & 0.000 & 0.004 \\
\hline \multirow{2}{*}{ Physical function } & $\mathrm{r}$ & -0.421 & -0.281 \\
\hline & $\mathrm{p}$ & 0.000 & 0.005 \\
\hline \multirow{2}{*}{ Pain } & $\mathrm{r}$ & -0.532 & -0.136 \\
\hline & $\mathrm{p}$ & 0.000 & 0.177 \\
\hline \multirow{2}{*}{ General health } & $\mathrm{r}$ & -0.330 & -0.386 \\
\hline & $\mathrm{p}$ & 0.001 & 0.000 \\
\hline \multirow{2}{*}{ Emotional wellbeing } & $\mathrm{r}$ & -0.697 & -0.338 \\
\hline & $\mathrm{p}$ & 0.000 & 0.001 \\
\hline \multirow{2}{*}{ Emotional function } & $\mathrm{r}$ & -0.456 & -0.335 \\
\hline & $\mathrm{p}$ & 0.000 & 0.001 \\
\hline \multirow{2}{*}{ Sexual function } & $\mathrm{r}$ & -0.390 & -0.180 \\
\hline & $\mathrm{p}$ & 0.000 & 0.073 \\
\hline \multirow{2}{*}{ Energy/fatigue } & $\mathrm{r}$ & -0.529 & -0.489 \\
\hline & $\mathrm{p}$ & 0.01 & 0.001 \\
\hline
\end{tabular}

\section{DISCUSSION}

The study sample can be described in terms of the sociodemographic characteristics as consisting of men, with a fixed partner and over 50 years of age. In addition, socioeconomic aspects like unfinished primary education and high frequency of professionally inactive individuals are observed. Overall, the incidence of systemic arterial hypertension was the main baseline disease for CRF. The aspects outlined in this study are in line with the Brazilian and international findings on the characteristics of renal patients. ${ }^{11,17-21}$

In this research, the mean anxiety and depression score, identified through the HADS, corre- 
sponded to $6.20( \pm 4.43)$ for anxiety and $4.08( \pm 3.43)$ for depression in CRF patients submitted to hemodialysis. Similarly, some authors had observed mean scores earlier in line with the present study. ${ }^{22-23} \mathrm{On}$ the opposite, in other studies, higher mean scores were identified. . $, 18,20-21^{2}$

Concerning the prevalence of anxiety and depression in the chronic renal patients in this study, $33.0 \%$ of anxiety and $16.0 \%$ of depression was observed. The findings support the similar percentage found in the literature, in which the prevalence of these mood disorders ranges between 5 and $45 \%$ in hemodialysis patients. ${ }^{4,6,18,20,23-24}$ Some factors related to the treatment can facilitate the manifestation of anxious and depressive symptoms, such as the need to adapt and loss of control over life due to the dependence on the machine, social isolation and deterioration of (physical and mental) functional performance. ${ }^{7,26}$

The treatment of CRF patients in hemodialysis prioritizes improvements in quality of life. Therefore, the variables that can interfere in the maintenance of a good QoL should be identified and modified. Anxiety and depression associated with hemodialysis contribute to the drop in QoL. ${ }^{6,18,20,24-25}$

What the quality of life is concerned, assessed by the Kidney Disease and Quality of Life ShortForm, the dimensions with the lowest scores were: Work status, Burden of kidney disease and Emotional function. On the opposite, the dimensions Cognitive function, Social support and Symptoms and problems obtained the highest scores. The highest mean score was for Cognitive function, but it should be highlighted that the chronic kidney patients are a risk population for cognitive decline. Thus, despite a good performance in this dimension, periodical assessment of the cognitive function is needed, in view of multiple risk factors for cognitive problems. ${ }^{19}$

In this study, it was observed that the mean scores in the domains were significantly lower in patients with anxiety and depression symptoms when compared to patients without any symptom, according to the cut-off point adopted. This finding is in accordance with what is described in the literature, in which the mean general QoL score of kidney patients under dialysis without anxiety and depression symptoms is higher in all domains when compared to patients with symptoms. ${ }^{6,25}$

A negative and moderate correlation was verified, specifically between the HADS-A and the dimensions Quality of social interaction, Pain, Emotional wellbeing and Energy/fatigue. Also, a negative and weak correlation was identified between
HADS-A and the domains Symptoms/problems, Effects of the disease, Burden of kidney disease, Physical function and Emotional function; and for the HADS-D with the Energy/fatigue dimension. That strengthens the hypothesis that the QoL drops as the presence of anxious and depressive symptoms increases, negatively affecting different aspects of the patients' life. ${ }^{6,18,22,26}$

These analyses permit inferences, driving the professionals' attention to the aspects that are influencing or modifying the quality of life based on the negative relation with anxiety and depression. That does not mean that the other dimensions can be neglected. Instead, time and individual factors should be taken into account. It is therefore subject to changes.

This knowledge can support the implementation of new strategies to contribute to the reduction of anxiety and depression symptoms, consequently improving the quality of life of individuals with CRF in hemodialysis. The application of tools to assess mood disorders and quality of life is necessary to quality care, such as the care nurses are responsible for.

It is important to highlight that, to analyze patients undergoing hemodialysis, it is not sufficient to only consider comorbidity and mortality rates, but to assess their quality of life, thus increasing the chances of rehabilitation. ${ }^{27}$ Many factors are representative in the quality of life measure of hemodialysis patients, such as age, comorbidities, sex, social factors, dialysis techniques, depression, anxiety, among others. Nevertheless, the quality of life varies with the person's vulnerability, making the hemodialysis an interference. ${ }^{7,23,26}$

Nursing professionals are responsible for managing the nursing process and, according to their conduct, coordinate a systemization that should approach people holistically, using strategies to minimize the anxiety and depression deriving from the disease and/or associated treatment, thus improving the clients' perceived HRQoL.

This research is limited by the cross-sectional design of the study, which makes it impossible to identify the order of precedence of the study factors, compromising the evidence on cause and effect relations.

What the interpretation of the results is concerned, the information obtained from the anxiety and depression scale and the quality of life questionnaire is self-referred and can therefore be influenced by cultural, language and education factors. On the opposite, the subjective measures provide valuable information on the quality of life of chronic renal 
patients under hemodialysis and the assessment tools used are validated and widely used in Brazil and around the world.

\section{CONCLUSION}

This study was relevant as it permitted measuring the depressive symptoms, anxiety symptoms and HRQoL of CRF patients undergoing hemodialysis, besides relating these aspects. The findings equip health professionals, particularly the nursing team, to plan, implement and assess possible interventions, aiming for effective, qualified and individual care, always targeting improvements in these people's quality of life.

In conclusion, a negative correlation exists between depression and anxiety and the HRQoL of chronic kidney patients under hemodialysis. In addition, the mean score on the KDQOL-SF domains was significantly lower in patients with the presence of anxious and/or depressive symptoms when compared to participants without these symptoms.

The HRQoL is an extremely important construct for people with severe and limiting chronic illnesses who submit to prolonged and painful treatments and are more vulnerable to comorbidities, like in the case of CRF patients under hemodialysis. The comparison of HRQoL with regard to the presence of anxious and/or depressive symptoms is important to assess the impact of the disease and the treatment on the living conditions and, thus, guide the care to these patients, individually and collectively, contributing to the improvement of quality of life.

\section{ACKNOWLEDGEMENTS}

To the Coordination for the Improvement of Higher Education Personnel (Capes) for funding.

\section{REFERENCES}

1. Bastos MG, Kirsztajn GM. Doença renal crônica: importância do diagnóstico precoce, encaminhamento imediato e abordagem interdisciplinar estruturada para melhora do desfecho em pacientes ainda não submetidos à diálise. J Bras Nefrol. 2011; 33(1):93-108.

2. Frazão CMFQ, Medeiros ABA, Silva FBBL, Lira ALBC. Nursing diagnoses in chronic renal failure patients on hemodialysis. Acta Paul Enferm. 2014; 27(1):40.

3. Lugon JR. Doença renal crônica no Brasil: um problema de saúde público. J Bras Nefrol. 2009; 31(1):2-5.

4. Stasiak CES, Bazan KS, Kuss RS, Schuinski AFM, Baroni G. Prevalência de ansiedade e depressão e suas comorbidades em pacientes com doença renal crônica em hemodiálise e diálise peritoneal. J Bras Nefrol. 2014; 36(3):325-31.

5. Feroze U, Martin D, Kalantar-Zadeh K, Kim JC, Reina-Patton A, Kopple JD. Anxiety and depression in maintenance dialysis patients: preliminary data of a cross-sectional study and brief literature review. J Ren Nutr.2012; 22(1):207-10.

6. Lee YJ, Kim MS, Cho S, Kim SR. Association of depression and anxiety with reduced quality of life in patients with predialysis chronic kidney disease. Int J Clin Pract. 2013; 67(4):363-8.

7. Bassola M, Ciciarelli C, Conte GL, Vulpio C, Luciani G, Tazza L. Correlates of symptoms of depression and anxiety in chronic hemodialysis patients. General Hospital Psychiatry. 2010; 32(2):125-31.

8. Riezebos RK, Nauta KJ, Honing A, Dekker FW, Siegertl CEH. The association of depressive symptoms with survival in a Dutch cohort of patients with endstage renal disease. Nephrol Dial Transplant. 2010; 25: 231-6.

9. Reis RK, Santos CB, Dantas RAS, Gir E. Qualidade de vida, aspectos sociodemográficos e de sexualidade de pessoas vivendo com HIV/AIDS. Texto Contexto Enferm. 2011; 20(3):565-75.

10. Seidl EMF, Zannon CMLC. Qualidade de vida e saúde: aspectos conceituais e metodológicos. Cad Saúde Pública. 2004; 20(2):580-8.

11. Braga SFM, Peixoto SV, Gomes IC, Acúrcio FA, Andrade EIG, Cherchiglia ML. Fatores Associados com uma Qualidade de Vida relacionada à saúde de Idosos em hemodiálise. Rev Saúde Pública. 2011; 45(6):1127-36.

12. Zigmond AS, Snaith RP. The hospital anxiety and depression scale. Acta Psychiat. Scand. 1983; 67:36170 .

13. Botega NJ, Bio MR, Zomignani MA, Garcia CJ, Pereira WAB. Transtornos do humor em enfermaria de clínica médica e validação de escala de medida (HAD) de ansiedade e depressão. Rev Saúde Publica. 1995; 29(5):355-63.

14. Duarte PS, Miyazaki MCOS, Ciconelli RM, Sesso R. Tradução e adaptação cultural do instrumento de avaliação de qualidade de vida para pacientes renais crônicos (KDQOL - SFT). Rev Assoc Med Bras. 2003; 49(4):375-81.

15. Pasquali L. Psicometria: Teoria dos testes na psicologia e na educação. $5^{\mathrm{a}}$ ed. Rio de Janeiro: Editora Vozes; 2013.

16. Levin, J, Fox J. Estatísticas para ciências humanas. $9^{a}$ ed. São Paulo: Pearson- Pretice Hall; 2004.

17. Ottaviani AC, Souza ER, Drago NC, Mendiondo MSZ, Pavarini SCI, Orlandi FS. Hope and spirituality among patients with chronic kidney disease undergoing hemodialysis: a correlational study. Rev Latino-Am Enfermagem. 2014; 22(2):248-54. 
18. Macuglia GR, Rossatto FC, Teixeira MAP, Giacomoni CH. Qualidade de vida e depressão de pacientes em hemodiálise. Rev Bras Ter Cogn. 2010; 6(2):167-86.

19. Condé SA, Fernandes N, Santos FR, Chaouab A, Mota MM, Bastos MG. Declínio cognitivo, depressão e qualidade de vida em pacientes de diferentes estágios da doença renal crônica. J Bras Nefrol. 2010; 32(3):242-8.

20. Griva K, Kang AW, Yu ZL, Mooppil NK, Foo M, Choong SPMC et al. Quality of life and emotional distress between patients on peritoneal dialysis versus community-based hemodialysis. Qual Life Res. 2014; 23:57-66.

21. Loosman WL, Siegert CEH,Korzec A, Honig A. Validity of the Hospital Anxiety and Depression Scale and the Beck Depression Inventory for use in end-stage renal disease patients. British J Clin Psychol. 2010; 49:507-16

22. Preljevic VT, Osthus RBH, Os IMD, Sandvik L, Opjordsmoen S, Nordhus IH et al. Anxiety and depressive disorders in dialysis patients: association to health-related quality of life and mortality. General
Hospital Psychiatry, 2013; 35:619-24.

23. Ramirez SP, Macêdo DS, Sales PMG, Figueiredo SM, Daher EF, Araújo SM et al. The relationship between religious coping, psychological distress and quality of life in hemodialysis patients. J Psych Res., 2012; 72: 129-35.

24. Varela L, Vazquez MI, Bolanos L, Alonso R. Psychological predictors for healthrelated quality of life in patients on peritoneal dialysis. Nefrologia. 2011; 31(1):97-106.

25. Ferreira RC, Silva Filho CR. Quality of life chronic renal patients on hemodialysis in Marília, SP, Brazil. J Bras Nefrol. 2011; 33(2):129-35.

26. Garcia TW, Veiga JPR, Motta LDC, Moura FJDM, Casulari LA. Depressed mood and poor quality of life in male patients with chronic renal failure undergoing hemodialysis. Rev Bras Psiquatr. 2010; 32(4):369-374.

27. Santos EB, Junior LJQ, Fraga BP, Macieira JC, Bonjardim LR. Avaliação dos sintomas de ansiedade e depressão em fibromiálgicos. Rev Esc Enferm USP. 2012; 46(3):590-6.
Correspondence: Fabiana de Souza Orlandi

Universidade Federal de São Carlos - Departamento de Gerontologia

Rodovia Washington Luís, km 235 - SP-310

13565-905 - São Carlos, SP, Brasil

E-mail: forlandi@ufscar.br
Received: March 03, 2015

Approved: February 12, 2016 